\title{
Inhibition of extracellular signal-regulated kinase $1 / 2$ signaling has beneficial effects on skeletal muscle in a mouse model of Emery-Dreifuss muscular dystrophy caused by lamin $A / C$ gene mutation
}

Antoine Muchir ${ }^{1,2,3^{*}}$, Young Jin Kim ${ }^{1,2,4}$, Sarah A Reilly ${ }^{1,2,5}$, Wei Wu ${ }^{1,2}$, Jason C Choi ${ }^{1,2}$ and Howard J Worman ${ }^{1,2^{*}}$

\begin{abstract}
Background: Autosomal Emery-Dreifuss muscular dystrophy is caused by mutations in the lamin A/C gene (LMNA) encoding A-type nuclear lamins, intermediate filament proteins of the nuclear envelope. Classically, the disease manifests as scapulo-humeroperoneal muscle wasting and weakness, early joint contractures and dilated cardiomyopathy with conduction block; however, move variable skeletal muscle involvement can be present. Previously, we demonstrated increased activity of extracellular signal-regulated kinase (ERK) $1 / 2$ in hearts of $L m n a^{H 222 P / H 222 P}$ mice, a model of autosomal Emery-Dreifuss muscular dystrophy, and that blocking its activation improved cardiac function. We therefore examined the role of ERK1/2 activity in skeletal muscle pathology.
\end{abstract}

Methods: Sections of skeletal muscle from $L m n a^{\mathrm{H} 222 \mathrm{P} / \mathrm{H} 222 \mathrm{P}}$ mice were stained with hematoxylin and eosin and histological analysis performed using light microscopy. ERK1/2 activity was assessed in mouse tissue and cultured cells by immunoblotting and real-time polymerase chain reaction to measure expression of downstream target genes. Lmna ${ }^{\mathrm{H} 222 \mathrm{P} / \mathrm{H} 222 \mathrm{P}}$ mice were treated with selumetinib, which blocks mitogen-activated protein kinase/extracellular signal-regulated kinase kinase 1/2 that activates ERK1/2, from 16 to 20 weeks of age to assess the effects of treatment on muscle histology, ERK1/2 activity and limb grip strength.

Results: We detected enhanced activation of ERK1/2 in skeletal muscle of $L m n a^{\mathrm{H} 222 \mathrm{P} / \mathrm{H} 222 \mathrm{P}}$ mice. Treatment with selumetinib ameliorated skeletal muscle histopathology and reduced serum creatine phosphokinase and aspartate aminotransferase activities. Selumetinib treatment also improved muscle function as assessed by in vivo grip strength testing.

Conclusions: Our results show that ERK1/2 plays a role in the development of skeletal muscle pathology in $\mathrm{Lmna}^{\mathrm{H} 222 / \mathrm{H} 222 \mathrm{P}}$ mice. They further provide the first evidence that a small molecule drug may be beneficial for skeletal muscle in autosomal Emery-Dreifuss muscular dystrophy.

Keywords: Muscular dystrophy, Nuclear envelope, Lamin, Selumetinib, Mitogen-activated protein kinase

\footnotetext{
* Correspondence: a.muchir@institut-myologie.org; hjw14@columbia.edu 'Department of Medicine, College of Physicians and Surgeons, Columbia University, 630 West 168th Street, New York, NY 10032, USA

${ }^{2}$ Department of Pathology and Cell Biology, College of Physicians and

Surgeons, Columbia University, New York, NY, USA

Full list of author information is available at the end of the article
} 


\section{Background}

Emery-Dreifuss muscular dystrophy (EDMD) is classically characterized clinically by a triad of: (1) slowly progressive muscle weakness and wasting in a scapulo-humeroperoneal distribution; (2) early contractures of the elbows, ankles, and posterior neck; and (3) dilated cardiomyopathy with conduction defects $[1,2]$. Contractures are usually the first clinical sign of the disease occurring in the first decade of life. During the second decade of life, the slowly progressive muscle weakness and wasting typically begin. At the end of the second decade, most patients develop evidence of cardiomyopathy [3-5].

EDMD can be inherited in a X-linked or autosomal fashion. X-linked EDMD is caused by mutations in EMD encoding emerin [6]. Emerin is an integral protein of the inner nuclear membrane $[7,8]$. The majority of autosomal dominant and less frequent recessive cases are caused by mutations in LMNA $[9,10]$. LMNA encodes two major somatic cell polypeptides, lamin A and lamin $\mathrm{C}$, which are components of the nuclear lamina, a meshwork of intermediate filaments on the inner aspect of the inner nuclear membrane [11-14]. While the classical EDMD phenotype was first attributed to EMD and LMNA mutations, it is now apparent that the same mutations in these genes can cause dilated cardiomyopathy with more variable skeletal muscle involvement [6,9,15-21]. Intriguingly, LMNA mutations (different than those leading to myopathy) can also cause partial lipodystrophy, peripheral neuropathy, or accelerated aging disorders such as Hutchinson-Gilford progeria syndrome [22].

Despite the relatively recent advances in understanding the genetics of EDMD and related myopathies, the pathogenic mechanisms leading to striated muscle damage are only poorly understood. One useful small animal model to study pathogenesis and evaluate potential therapeutic interventions in autosomal EDMD is the Lmna ${ }^{\mathrm{H} 222 \mathrm{P} / \mathrm{H} 222 \mathrm{P}}$ mouse [23]. Starting at approximately 16 weeks, male Lmna $^{\mathrm{H} 222 \mathrm{P} / \mathrm{H} 222 \mathrm{P}}$ develop progressive dystrophic pathology in several skeletal muscle groups. Later, they have progressive accumulation of connective tissue in skeletal muscle. Lmna $^{\mathrm{H} 222 \mathrm{P} / \mathrm{H} 222 \mathrm{P}}$ mice also develop dilated cardiomyopathy with conduction system abnormalities and significant cardiac fibrosis.

We have previously shown that Lmna ${ }^{\mathrm{H} 222 \mathrm{P} / \mathrm{H} 222 \mathrm{P}}$ mice have increased activity of the mitogen-activated protein kinase extracellular signal-regulated kinase (ERK) $1 / 2$ in cardiac muscle [24]. This increased ERK1/2 activity occurs prior to the onset of overt tissue pathology, suggesting that it plays a primary pathogenic role. Treatment of Lmna ${ }^{\mathrm{H} 222 \mathrm{P} / \mathrm{H} 222 \mathrm{P}}$ mice with drugs that inhibit mitogenactivated protein kinase/extracellular signal-regulated kinase kinase (MEK) 1/2, the kinase that activates ERK1/2, leads to improved left ventricular ejection fraction $[25,26]$, decreased cardiac fibrosis [26,27] and prolonged survival
[27]. While these results strongly suggest that abnormal ERK1/2 activation contributes to the development of cardiomyopathy in $L m n a^{\mathrm{H} 222 \mathrm{P} / \mathrm{H} 222 \mathrm{P}}$ mice, its pathogenic role in affected skeletal muscles is unknown.

Based on our findings in heart, we hypothesize that abnormal activation of ERK1/2 is similarly involved in the pathogenesis of skeletal muscular dystrophy in the $L m n a^{\mathrm{H} 222 \mathrm{P} / \mathrm{H} 222 \mathrm{P}}$ mouse model of EDMD. In the present study, we demonstrate increased activation of ERK1/2 in affected skeletal muscle these mice. We further show that treatment with the MEK1/2 inhibitor selumetinib ameliorates pathological changes and improves function. These results suggest that MEK1/2 inhibitors may be beneficial in treating both cardiac and skeletal muscle disease in patients with EDMD.

\section{Methods}

Mice

Lmna ${ }^{\mathrm{H} 222 \mathrm{P} / \mathrm{H} 222 \mathrm{P}}$ mice were bred and genotyped as previously described [23]. Mice were fed chow and housed in a disease-free barrier facility with $12 \mathrm{~h} / 12 \mathrm{~h}$ light/dark cycles. The Institutional Animal Care and Use Committee at Columbia University Medical Center approved the use of animals and the study protocols.

\section{Drug treatment protocol and harvesting of muscle samples}

Selumetinib (Selleck Chemicals) was dissolved in dimethyl sulfoxide (DMSO) (Sigma) at a concentration of $0.5 \mathrm{mg} /$ $\mathrm{mL}$ to allow for intraperitoneal injections in mice. The placebo control consisted of the same volume of DMSO. Selumetinib was delivered at a dose of $1 \mathrm{mg} / \mathrm{kg}$ daily by intraperitoneal injection using a 27 5/8-gauge syringe starting when mice were 16 weeks of age and continuing until 20 weeks of age. At the end of the study, mice were sacrificed and hindlimb and diaphragm muscles dissected. Part of each dissected muscle was frozen in liquid nitrogen and stored at $-80^{\circ} \mathrm{C}$ for biochemical analysis. The remaining muscle was rapidly frozen in isopentane pre-chilled by liquid nitrogen for cryostat sectioning.

\section{Histology}

Frozen pieces of quadriceps femoris, diaphragm, and tibialis anterior were mounted in Tissue-Tek (Fisher Scientific) and $10 \mu \mathrm{m}$ sections cut on a cryostat. Sections were stained with hematoxylin and eosin for histological analysis. Representative sections were photographed using a Microphot SA (Nikon) light microscope attached to a Spot RT Slide camera (Diagnostic Instruments). Images were processed using Adobe Photoshop CS (Adobe Systems).

\section{Osmotic shock of $\mathrm{C} 2 \mathrm{C} 12$ cells stably expression wild-type and $\mathrm{H} 222 \mathrm{P}$ lamin $\mathrm{A}$}

Generation of stable $\mathrm{C} 2 \mathrm{C} 12$ cells expressing wild-type and H222P lamin A has been described previously [28]. 


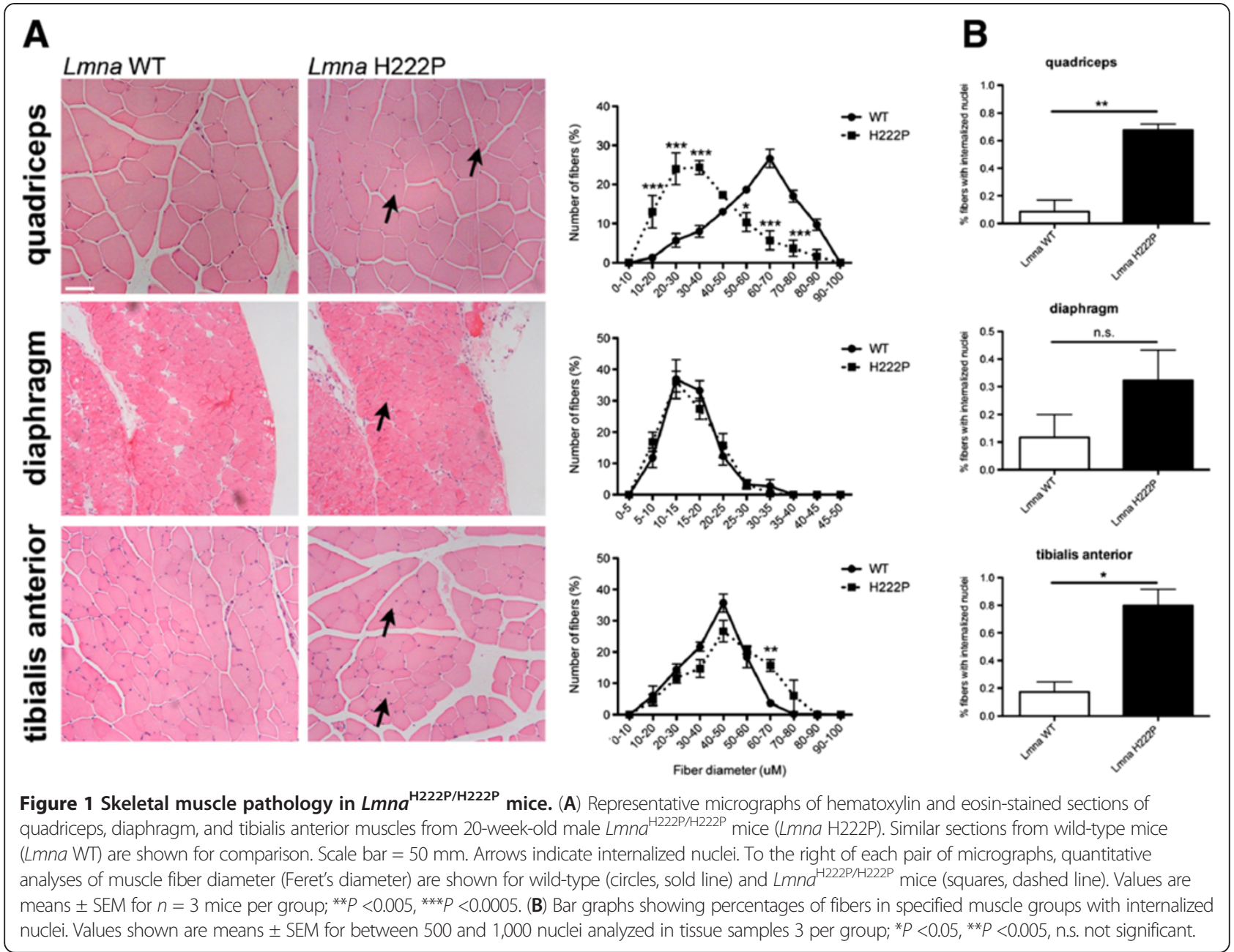

These cells were maintained at $37^{\circ} \mathrm{C}$ with $5 \% \mathrm{CO}_{2}$ and subcultured at approximately $60 \%$ to $70 \%$ confluence in Dulbecco's modified Eagle's medium supplemented with $10 \%$ fetal bovine serum (Invitrogen). To assess the impact of osmotic shock on the activation of ERK1/2, cells were treated with D-sorbitol $(600 \mathrm{mM})$ for $1 \mathrm{~h}$ and proteins were harvested in RIPA extraction buffer (Cell Signaling Technology) as previously described [24].

\section{Quantitative real-time reverse transcription-polymerase chain reaction (RT-PCR)}

Total RNA was extracted using the RNeasy isolation kit (Qiagen). Total RNA was used to synthesize cDNA using SuperScript First-strand Synthesis System (Invitrogen) according to the manufacturer's instructions. For each replicate in each experiment, RNA from tissue samples of different animals was used. Primers were designed corresponding to mouse RNA sequences using Primer3 [29]. Real-time quantitative RTPCR reactions contained HotStart-IT SYBR green qPCR Master Mix (Affymetrix), $200 \mathrm{nM}$ of each primer and $0.2 \mu \mathrm{L}$ of template in a reaction volume of $25 \mu \mathrm{L}$. Amplification was carried out using the ABI 7300 Real-time PCR System (Applied Biosystems). Relative levels of mRNA expression were calculated using the $\Delta \Delta C_{T}$ method [30] and individual expression values were normalized by comparison to Gapdh mRNA.

\section{Protein extraction and immunoblotting}

Skeletal muscle was homogenized in RIPA extraction buffer (Cell Signaling Technology) as previously described [24]. Extracted proteins were separated by SDSpolyacrylamide gel electrophoresis, transferred to nitrocellulose membranes, and blotted with primary antibodies against ERK1/2 and phosphorylated ERK1/2 (Cell Signaling Technology). Secondary antibodies were horseradish peroxidate-conjugated (GE Healthcare). Recognized proteins were visualized by enhanced chemiluminescence (GE Healthcare). To quantify results, the immunoblots were scanned and band densities calculated using ImageJ64 (Applied Imaging). Signals obtained for phosphorylated ERK1/2 were normalized to those for total ERK1/2. 


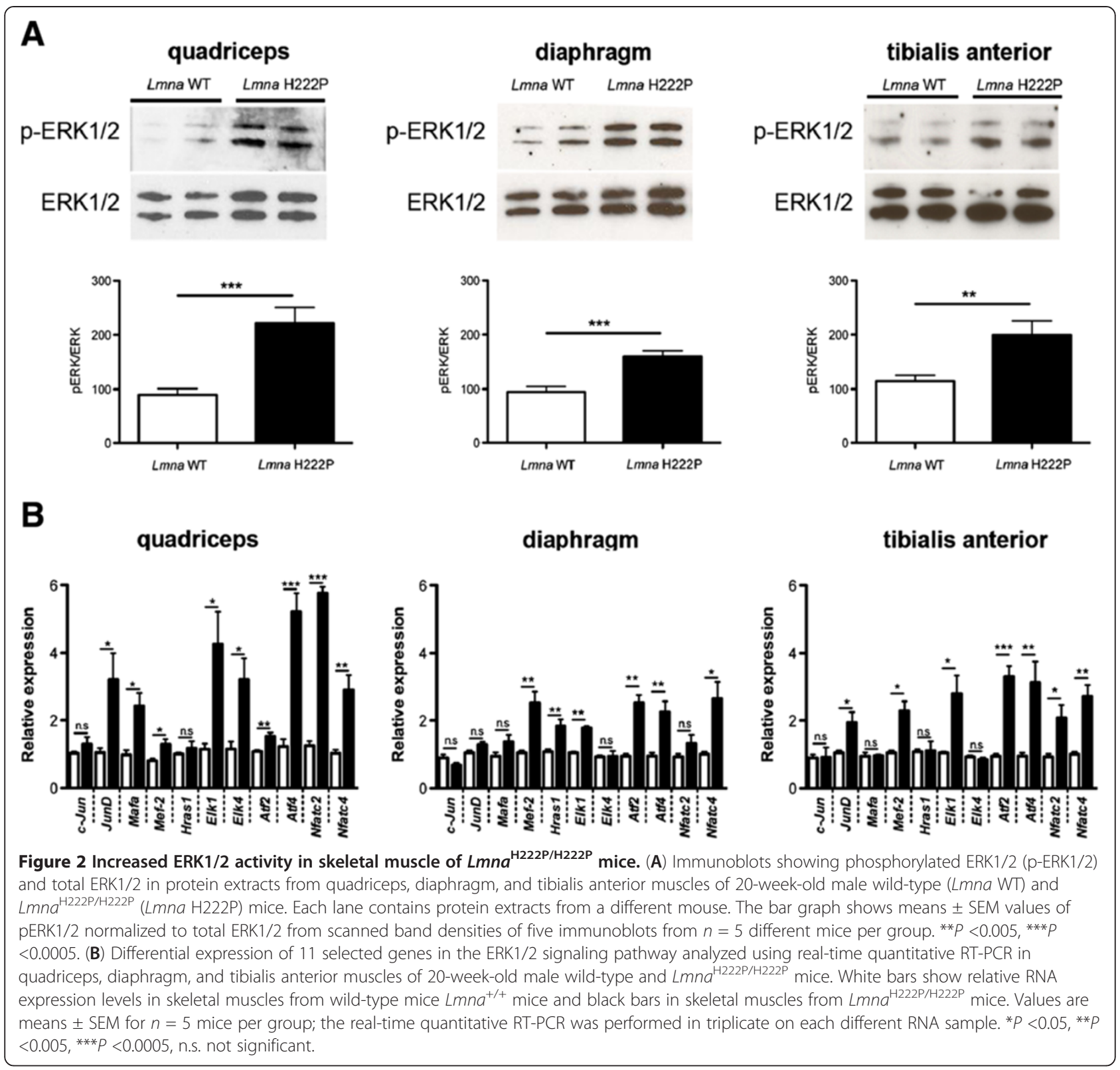

\section{Serum biochemistry}

Serum was separated from mouse blood and stored at $-80^{\circ} \mathrm{C}$ for 3 to 9 months until analyzed. Creatine phosphokinase (CPK) and aspartate aminotransferase (AST) activities were measured using an Analyst III Analyzer (Hemagen Diagnostics) in the Comparative Pathology Laboratory at Columbia University Medical Center. CPK and AST activities have been shown to be stable in rodent serum stored for up to 360 days at $-70^{\circ} \mathrm{C}[31]$.

\section{Limb grip strength measurements}

Lmna ${ }^{\mathrm{H} 222 \mathrm{P} / \mathrm{H} 222 \mathrm{P}}$ mice treated with DMSO or selumetinib were subjected to limb grip strength testing using a horizontally positioned grip strength meter (Bioseb). Mice were lowered by the tail towards the grid on the apparatus. Upon grasping the grid with their limbs, mice were pulled backward in the horizontal plane. The procedure was repeated consecutively three times and the peak tension of the three pulls was recorded as the grip strength value. Each animal was subjected to a total of two serial trials of three pulls each with $20 \mathrm{~s}$ of rest in between.

\section{Statistics}

Values for real-time quantitative RT-PCR, scanned immunoblots, internalized nuclei, serum CPK and AST activities, and grip strength were compared using an unpaired Student t-tests. Values for Feret's diameter were compared using two-way ANOVA. Statistical 


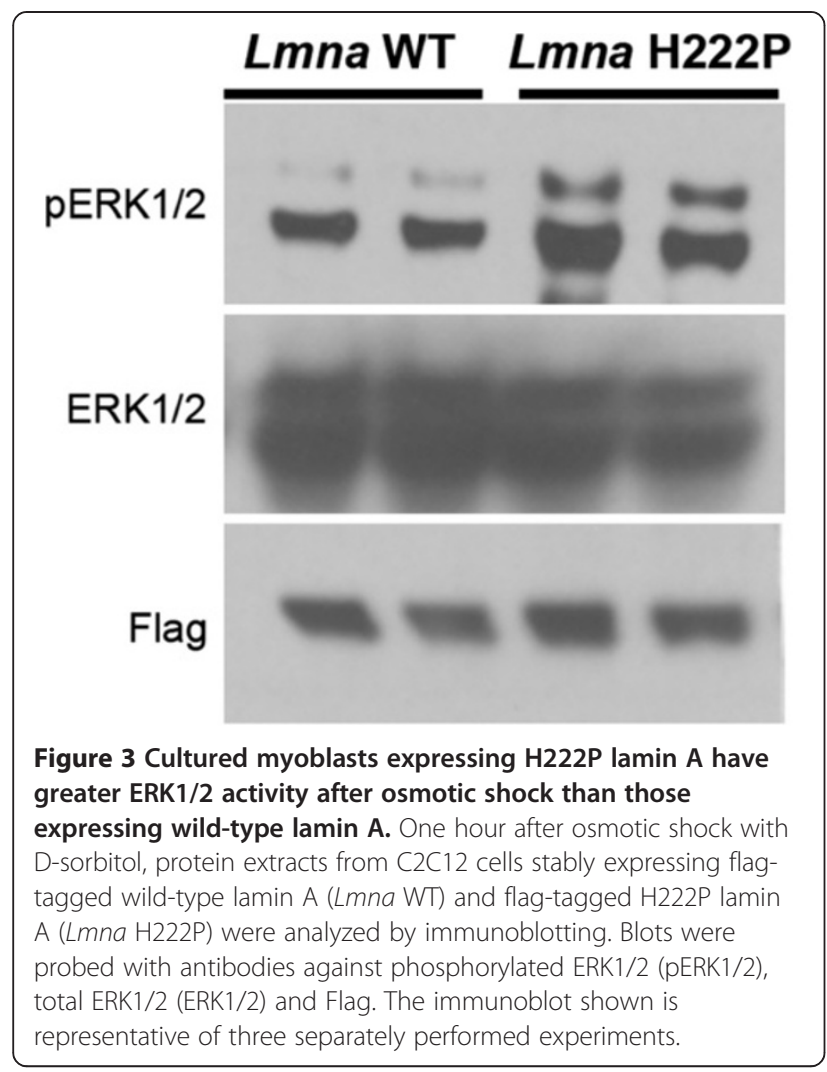

analyses were performed using Prism (GraphPad Software).

\section{Results and discussion}

Dystrophic skeletal muscle pathology in $L m n a^{\mathrm{H} 222 \mathrm{P} / \mathrm{H} 222 \mathrm{P}}$ mice

Arimura et al. [23] previously reported progressive dystrophic changes in skeletal muscle starting at 16 weeks male Lmna ${ }^{\mathrm{H} 222 \mathrm{P} / \mathrm{H} 222 \mathrm{P}}$ mice. Their non-quantitative histopathological analysis included descriptions of a wide variation in fiber size, an increased number of atrophic, hypertrophic, and lobulated fibers, some regenerative fibers and a mention that some fibers had internalized nuclei. We therefore carefully quantified myofiber diameters and internalized nuclei in histological sections of quadriceps, diaphragm, and tibialis anterior muscle of male wild-type and $L m n a^{\mathrm{H} 222 \mathrm{P} / \mathrm{H} 222 \mathrm{P}}$ mice at 20 weeks of age. Compared to wild-type mice, quadriceps and tibialis anterior from the Lmna ${ }^{\mathrm{H} 222 \mathrm{P} / \mathrm{H} 222 \mathrm{P}}$ mice exhibited a wider variation in fiber size (Figure 1A). In quadriceps, there was a clear shift towards smaller fiber diameters, consistent with the presence of greater numbers of atrophic and regenerative fibers. Both of these muscle groups also had an increased percentage of fibers with internal nuclei, which is observed during regeneration (Figure 1A,B). At this age, however, diaphragm did not show significant differences between Lmna ${ }^{\mathrm{H} 22 \mathrm{P} / \mathrm{H} 222 \mathrm{P}}$ and wild-type mice (Figure 1A,B).

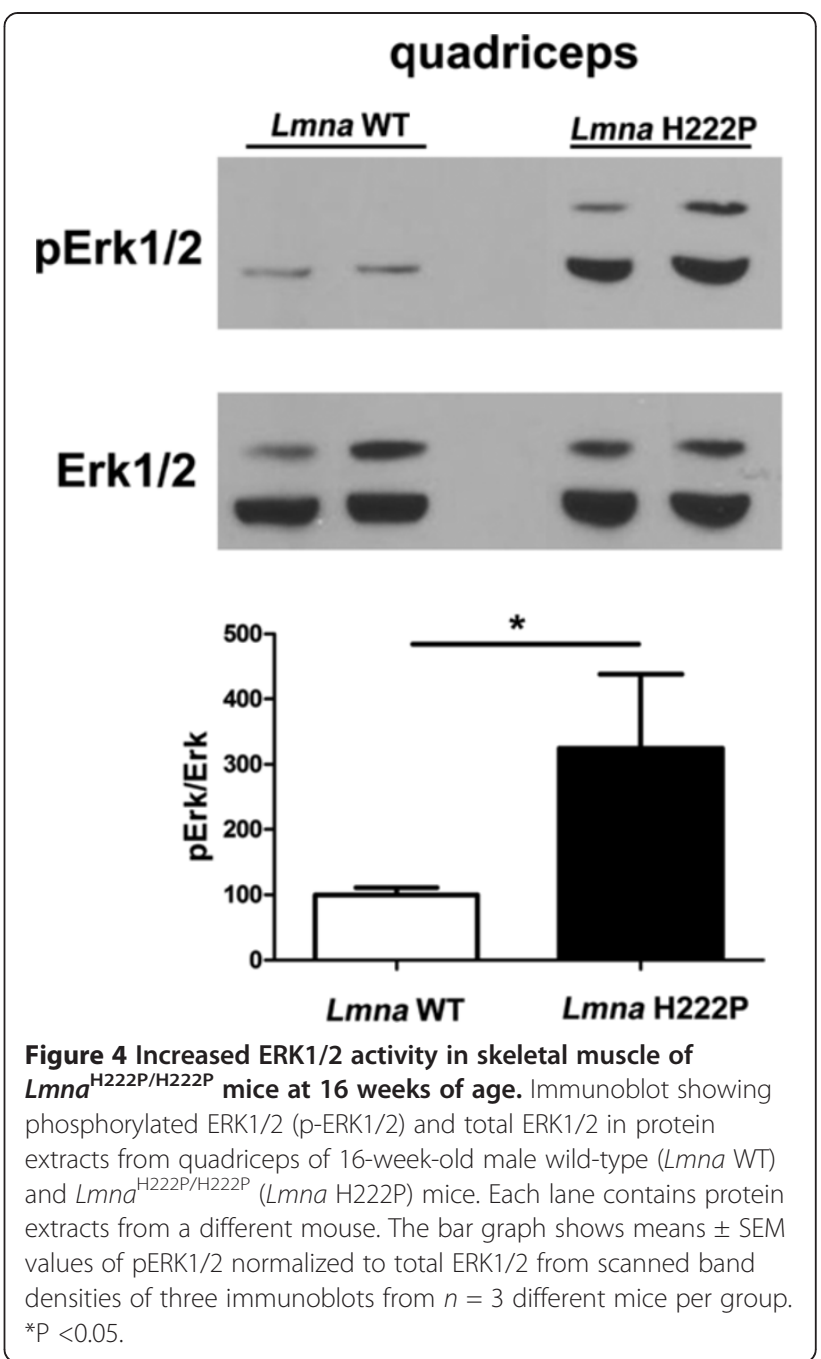

Abnormal ERK $1 / 2$ signaling in skeletal muscle of Lmna ${ }^{\mathrm{H} 222 \mathrm{P} / \mathrm{H} 222 \mathrm{P}}$ mice

Hearts of Lmna ${ }^{\mathrm{H} 222 \mathrm{P} / \mathrm{H} 222 \mathrm{P}}$ mice and human subjects with autosomal EDMD have increased activity of ERK1/ 2 , which likely plays a role in pathogenesis of cardiomyopathy [24-27]. We hypothesized that a similar increased activation of this signaling pathway occurs in skeletal muscle. We therefore examined ERK1/2 activity in skeletal muscle from 20-week-old male $L m n a^{\mathrm{H} 222 \mathrm{P} / \mathrm{H} 222 \mathrm{P}}$ mice. Immunoblotting with antibody against phosphorylated (activated) ERK1/2 demonstrated a two-fold increase in activity in quadriceps, diaphragm, and tibialis anterior of $L m n a^{\mathrm{H} 222 \mathrm{P} / \mathrm{H} 222 \mathrm{P}}$ mice compared to wild type mice (Figure 2A). We then used quantitative real-time PCR to measure expression of downstream ERK1/2 target genes, several of which are members of the ETS family of transcription factors that are phosphorylated by ERK1/2 and positively autoregulate their transcriptional activity [24,32,33]. Of 11 targets genes assessed, we detected significantly increased expression of mRNAs 


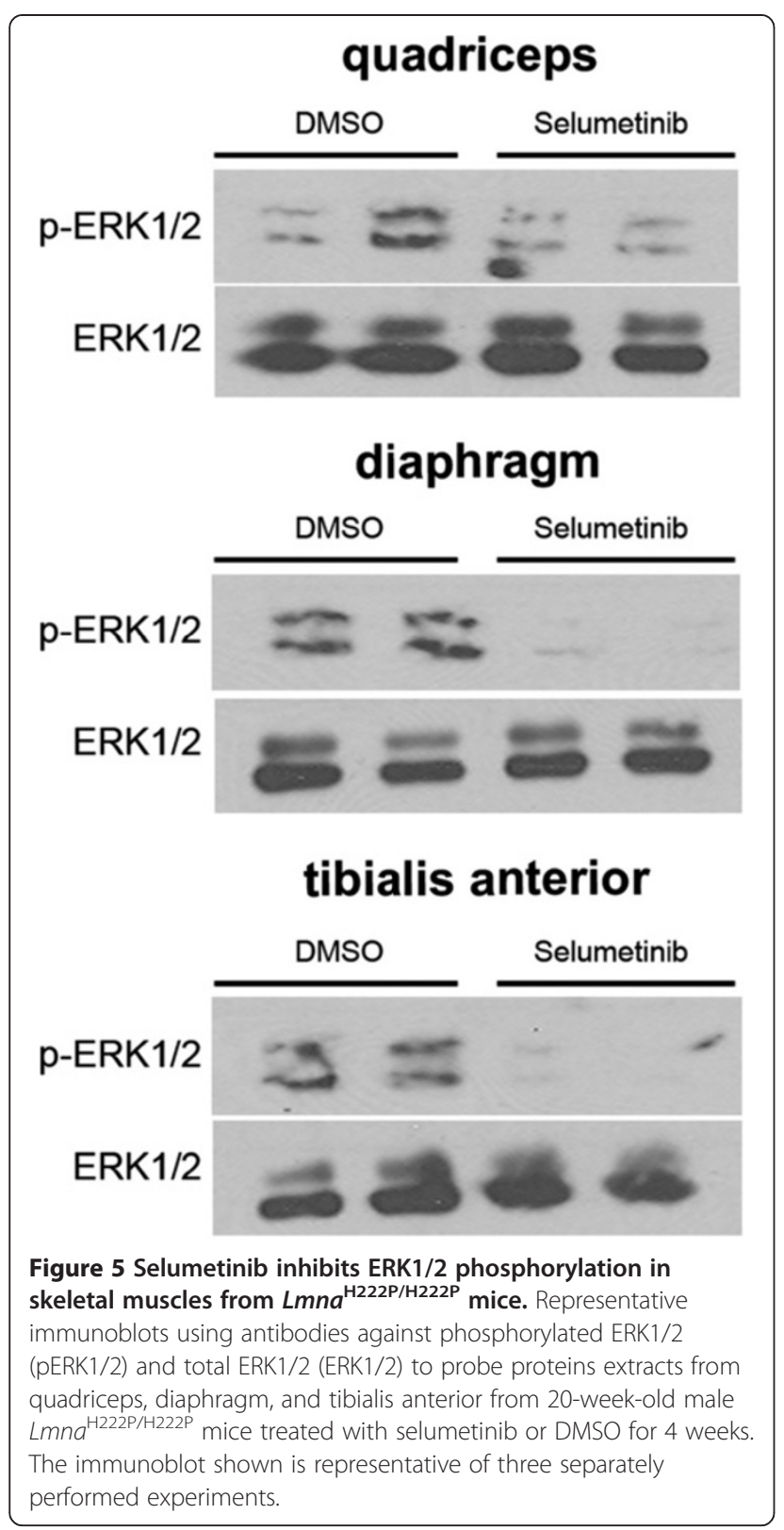

for nine in quadriceps, six in diaphragm, and seven in tibialis anterior of Lmna ${ }^{\mathrm{H} 222 \mathrm{P} / \mathrm{H} 222 \mathrm{P}}$ mice compared to wildtype controls (Figure 2B). Among these, Mef-2, Elk1, Atf2, Atf4, and Nfatc-4 showed significantly increased expression in the three skeletal muscles examined. These data demonstrate that ERK1/2 is hyperactivated in the skeletal muscles of $L m n a^{\mathrm{H} 222 \mathrm{P} / \mathrm{H} 222 \mathrm{P}}$ mice. Increased ERK1/2 activation in diaphragm at an age before there is any detectable histological abnormalities is consistent with its increased activity in heart prior to the onset of detectable pathological signs of cardiomyopathy [24]. This suggests that increased ERK1/2 signaling is involved in the pathogenesis of dystrophic skeletal muscle pathology.
Stress-induced activation of ERK1/2 in cultured myoblasts stably expressing $\mathrm{H} 222 \mathrm{P}$ lamin A

We have previously shown that transient transfection of C2C12 mouse myoblasts with cDNA encoding H222P prelamin A or other variants associated with striated muscle disease have increased ERK $1 / 2$ activity compared to those transfected with a cDNA encoding wild-type prelamin A [24]. However, stably transfected C2C12 cells expressing H222P lamin A do not have increased ERK1/ 2 activity at baseline but do after glucose depravation or treatment with 5-aminoimidazole-4-carboxyamide ribonucleoside [28]. This led us to hypothesize that physiological stress, such as that associated with manipulations necessary for transient transfection or induced by altered energy metabolism, is necessary to increase ERK1/2 activity in myoblasts expressing lamin A variants. We further tested this hypothesis by subjecting the same cells stably expressing lamin A H222P that do not have baseline elevation in ERK1/2 [28] to osmotic shock. One hour after an osmotic shock with $600 \mathrm{mM}$ D-sorbitol, cells expressing flag-tagged H222P lamin A had a greater activity of ERK1/2 compared to those expressing flagtagged wild-type lamin A (Figure 3 ). This result provided additional support for a model in which alterations in the nuclear lamina associated with striated muscle disease lead to abnormalities in the activities of cellular stress-responsive signaling pathways $[24,34,35]$. The requirement of a stress to hyperactivate ERK1/2 in cells expressing the H222P lamin A may also at least in part explain why striated muscle, a tissue repeatedly under mechanical strain, is preferentially affected by $L M N A$ mutations generating certain A-type lamin variants.

\section{Blocking ERK1/2 activity with selumetinib has beneficial} effects on skeletal muscle in Lmna ${ }^{\mathrm{H} 222 \mathrm{P} / \mathrm{H} 222 \mathrm{P}}$ mice

Given the enhanced ERK1/2 activity in skeletal muscle of Lmna ${ }^{\mathrm{H} 222 \mathrm{P} / \mathrm{H} 222 \mathrm{P}}$ mice that develop muscular dystrophy, we hypothesized that it may contribute to pathology. To test this hypothesis, we set up experiments to determine if inhibiting ERK1/2 signaling would prevent the progression of muscular dystrophy. At 16 weeks of age, ERK1/2 activity was elevated in quadriceps muscle of $L m n a^{\mathrm{H} 222 \mathrm{P} / \mathrm{H} 222 \mathrm{P}}$ mice compared to wild-type mice, as assessed by immunoblotting with antibody against phosphorylated kinase (Figure 4).

We administered the MEK1/2 inhibitor selumetinib to male $L m n a^{\mathrm{H} 222 \mathrm{P} / \mathrm{H} 222 \mathrm{P}}$ mice by giving daily intraperitoneal injections $(1 \mathrm{mg} / \mathrm{kg})$ starting at 16 weeks of age. After 4 weeks of treatment, the mice had reduced phosphorylated ERK1/2 in quadriceps, tibialis anterior, and diaphragm compared to placebo-treated mice. This demonstrated that systemically administered selumetinib inhibited ERK1/2 signaling in skeletal muscle (Figure 5). 


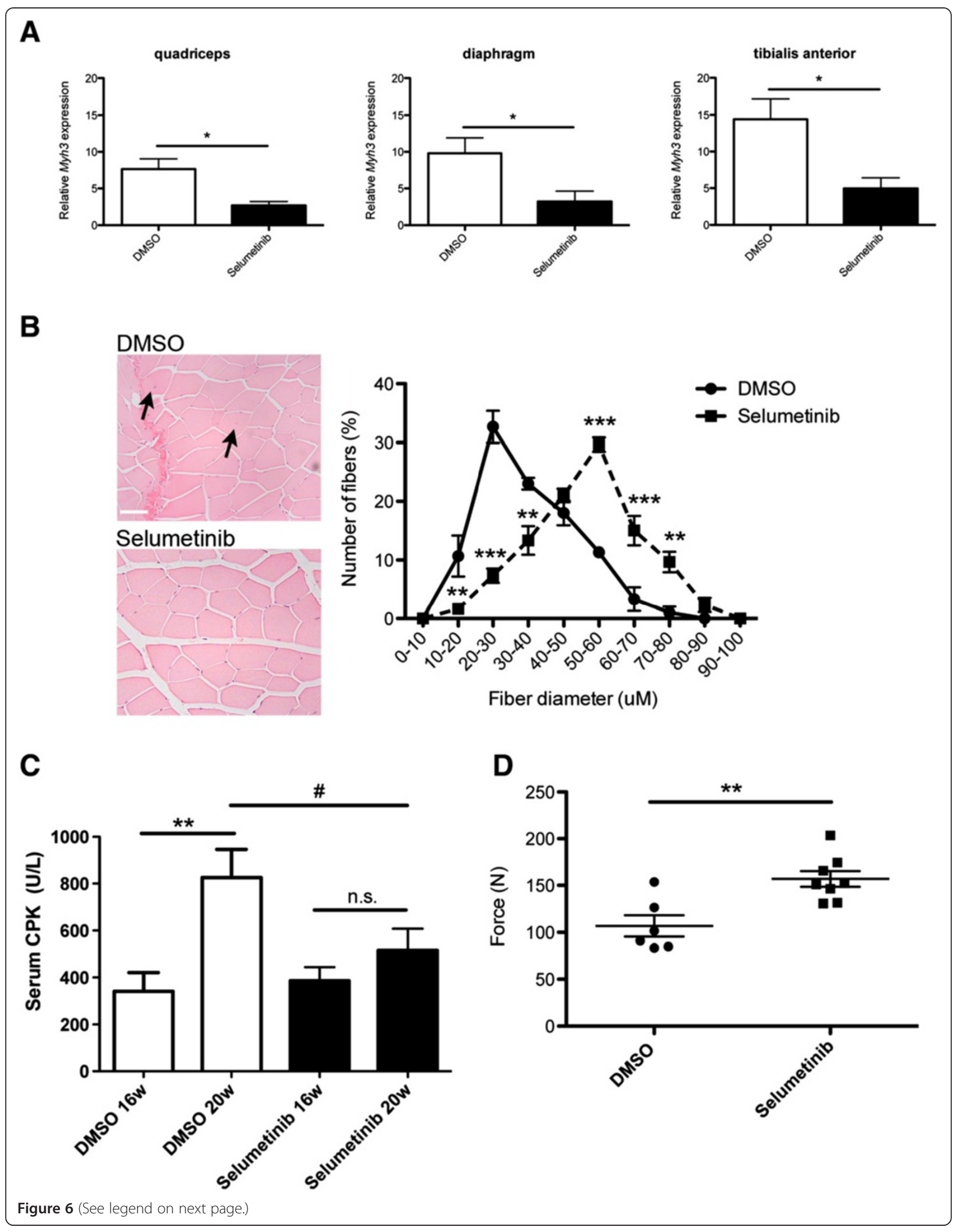


(See figure on previous page.)

Figure 6 Selumetinib from 16 to 20 weeks of age improves skeletal muscle pathology and function in $\operatorname{Lmna}^{\mathrm{H} 222 \mathrm{P} / \mathrm{H} 222 \mathrm{P}}$ mice.

(A) Expression of Myh3 in Lmna ${ }^{\mathrm{H} 222 \mathrm{P} / \mathrm{H} 222 \mathrm{P}}$ mice measured using real-time quantitative RT-PCR. White bars show relative RNA expression levels in skeletal muscles of DMSO-treated (white bars) and selumetinib-treated (black bars) mice. Values are means \pm SEM for $n=5$ mice per group; the real time RT-PCR was performed in triplicate with the different RNA sample; ${ }^{*} P<0.05$. (B) Representative micrographs of hematoxylin and eosinstained sections of quadriceps from 20-week-old male $L m n a^{\mathrm{H} 222 \mathrm{P} / \mathrm{H} 222 \mathrm{P}}$ mice ( $\left.L m n a \mathrm{H} 222 \mathrm{P}\right)$ treated for 4 weeks with DMSO or selumetinib. Scale bar $=50 \mathrm{~mm}$. Arrows indicate internalized nuclei. To the right of the micrographs, quantitative analyses of muscle fiber diameter (Feret's diameter) are shown for mice treated with DMSO (circles, solid line) and selumetinib (squares, sold line). Values are means \pm SEM for $n=3$ mice per group; ${ }^{* * P}<0.005,{ }^{* * P}<<0.0005$. (C) Serum CPK activities in $L m n a^{\mathrm{H} 222 \mathrm{P} / \mathrm{H} 222 \mathrm{P}}$ mice at 16 weeks $(16 \mathrm{~W})$ and 20 weeks $(20 \mathrm{~W})$ of age that were treated with DMSO (white bars) or selumetinib (black bars). Values are means \pm SEM for $n=7$ DMSO-treated mice and $n=15$ selumetinibtreated mice; ${ }^{* * P}<0.005$, n.s. not significant, ${ }^{\#} P<0.05$. (D) Grip strength (force) in Newtons (N) in $L m n a^{\mathrm{H} 222 P / H 222 \mathrm{P}}$ mice at 20 weeks of age that were treated with DMSO (circles) $(n=6)$ or selumetinib (squares) $(n=8)$. Each circle and square represents a measurement from an individual mouse; the longer horizontal bar are means and the shorter horizontal bars \pm SEM; ${ }^{* *} \mathrm{P}<0.05$.

Following 4 weeks of treatment with selumetinib, there was significantly reduced expression of embryonic myosin heavy chain (Myh3) mRNA in quadriceps, diaphragm, and tibialis anterior of $L m n a^{\mathrm{H} 222 \mathrm{P} / \mathrm{H} 222 \mathrm{P}}$ mice (Figure 6A). This represented a partial reversal of embryonic myosin expression that typically occurs in dystrophic muscle [36,37]. While quadriceps from DMSO-treated mice had $0.52 \%$ fibers (4/772 from three mice) with internalized nuclei (Figure 6A, arrows), there were none detected in 571 fibers from three mice in the selumetinibtreated mice (and 1/604 fibers from three wild-type mice as shown in Figure 1B). DMSO treatment did not impact myofiber diameter compared to untreated $L m n a^{\mathrm{H} 222 \mathrm{P} / \mathrm{H} 222 \mathrm{P}}$ mice; however, mice treated with selumetinib had a greater myofiber diameter in quadriceps compared to those treated with DMSO (Figure 6B). Between 16 and 20 weeks of age, there was a significant increase in serum CPK activity in Lmna $^{\mathrm{H} 222 \mathrm{P} / \mathrm{H} 222 \mathrm{P}}$ mice treated with DMSO; however, CPK activity did not significantly increase in the mice that received selumetinib and at 20 weeks it was significantly lower than in those that received DMSO (Figure 6C). Mean serum AST activity was also significantly lower in the selumetinib-treated mice compared to the placebotreated mice at 20 weeks of age (data not shown). To determine if selumetinib improved skeletal muscle function in $L m n a^{\mathrm{H} 222 \mathrm{P} / \mathrm{H} 222 \mathrm{P}}$ mice, we evaluated limb grip strength. At 20 weeks of age, mean grip strength was significantly greater in selumetinib-treated $L m n a^{\mathrm{H} 222 \mathrm{P} / \mathrm{H} 222 \mathrm{P}}$ mice than in DMSO-treated mice (Figure 6D). Hence, selumetinib improved skeletal muscle dystrophic pathology and improved function in $L m n a^{\mathrm{H} 222 \mathrm{P} / \mathrm{H} 222 \mathrm{P}}$ mice.

\section{Conclusions}

We have shown increased activity of ERK1/2 in skeletal muscle of the Lmna ${ }^{\mathrm{H} 222 \mathrm{P} / \mathrm{H} 222 \mathrm{P}}$ mouse model of autosomal EDMD and that blocking its activity ameliorates pathology. These results are in accordance with a growing body of research providing evidence that alterations in various cellular signaling pathways, including ERK1/2, are involved in the pathogenesis of muscular dystrophy [38]. In addition to autosomal EDMD, ERK1/2 has been implicated as contributing to skeletal or cardiac muscle pathology in $m d x$ [39-41], $\gamma$-sarcoglycan-deficient [42,43], and Lama $2^{\text {Dy-w }}$ [44] mice, respective small animal models of Duchenne, limb girdle type $2 \mathrm{C}$, and a form of congenital muscular dystrophy. ERK1/2 activity is also abnormally increased in hearts of mice with emerin deficiency, which is the genetic alteration in X-linked EDMD [45].

Blocking increased ERK1/2 signaling activity with selumetinib had beneficial effects on skeletal muscle function in Lmna ${ }^{\mathrm{H} 222 \mathrm{P} / \mathrm{H} 222 \mathrm{P}}$ mice. Previously, we obtained similar results with respect to the cardiomyopathy that occurs in these mice [24-27]. In a human clinical trial, selumetinib has been reported to promote muscle gain in patients with cholangiocarcinoma [46]. As oral selumetinib and other orally bioavailable MEK1/2 inhibitors with encouraging safety profiles are currently in clinical development for other indications $[47,48]$, pilot trials in patients with EDMD and possibly other muscular dystrophies should be considered.

\section{Abbreviations}

AST: Aspartate aminotransferase; CPK: Creatine phosphokinase; DMSO: Dimethyl sulfoxide; EDMD: Emery-Dreifuss muscular dystrophy; ERK: Extracellular signal-regulated kinase; LMNA: Lamin A/C gene; MEK: Mitogen-activated protein kinase/extracellular signal-regulated kinase kinase; RT-PCR: Reverse transcription-polymerase chain reaction.

\section{Competing interests}

AM and HJW are inventors on a pending patent application (PCT/USO9/ 42614) on methods for treating and/or preventing cardiomyopathies by ERK and JNK inhibition filed by the Trustees of Columbia University in the City of New York.

\section{Authors' contributions}

AM conceived of the study, bred mice, treated mice with drugs, carried out experiments measuring ERK1/2 activity in mouse tissue and cells, assessed skeletal muscle pathology and grip strength in mice, and drafted the manuscript. YJK carried out experiments on measuring ERK1/2 activity in mouse tissue and cells and assessing skeletal muscle pathology in mice. SAR assisted with isolating skeletal muscle form mice and participated in experiments measuring ERK1/2 activity in mouse tissue. WW bred mice, drew blood from mice, and assisted in treating mice with drugs. JCC generated stable cell lines expressing $\mathrm{H} 222 \mathrm{P}$ and wild type lamin A. HJW helped conceive the study, supervised and coordinated all of the research, and wrote the final manuscript. All of the authors read and approved the final manuscript. 


\section{Acknowledgements}

We thank Dr. Gisèle Bonne (Institut de Myologie) for providing Lmna ${ }^{\mathrm{H} 222 \mathrm{P} / \mathrm{H} 222 \mathrm{P}}$ mice and Dr. Michio Hirano (Columbia University) for assistance with grip strength testing. This work was supported by grants from the National Institutes of Health/National Institute of Arthritis and Musculoskeletal and Skin Diseases (AR048997) and Los Angeles Thoracic and Cardiovascular Foundation to HJW and a grant from the Association Franaçise Contre les Myopathies to AM.

\section{Author details}

'Department of Medicine, College of Physicians and Surgeons, Columbia University, 630 West 168th Street, New York, NY 10032, USA. ${ }^{2}$ Department of Pathology and Cell Biology, College of Physicians and Surgeons, Columbia University, New York, NY, USA. ${ }^{3}$ Current address: Therapie des maladies du muscle strie, Institut de Myologie UM76 - UPMC Univ. Paris 6, U974 - Inserm, UMR7215 - CNRS G.H., F-75651 Paris, Cedex 13, France. ${ }^{4}$ Current address: Stony Brook University School of Medicine, Stony Brook, NY 11794, USA. ${ }^{5}$ Current address: Tufts University School of Medicine, Boston, MA 02111, USA.

Received: 3 January 2013 Accepted: 22 April 2013

Published: 1 July 2013

\section{References}

1. Emery AEH, Dreifuss FE: Unusual type of benign X-linked muscular dystrophy. J Neurol Neurosurg Psychiatry 1966, 29:338-342.

2. Emery AE: X-linked muscular dystrophy with early contractures and cardiomyopathy (Emery-Dreifuss type). Clin Genet 1987, 32:360-367.

3. Waters DD, Nutter DO, Hopkins LC, Dorney ER: Cardiac features of an unusual X-linked humeroperoneal neuromuscular disease. N Engl J Med 1975, 293:1017-1022.

4. Bécane HM, Bonne G, Varnous S, Muchir A, Ortega V, Hammouda EH, Urtizberea JA, Lavergne T, Fardeau M, Eymard B, Weber S, Schwartz K, Duboc D: High incidence of sudden death of conduction system and myocardial disease due to lamins A/C gene mutation. Pacing Clin Electrophysiol 2000, 23:1661-1666.

5. van Berlo JH, de Voogt WG, van der Kooi AJ, van Tintelen JP, Bonne G, Yaou RB, Duboc D, Rossenbacker T, Heidbüchel H, de Visser M, Crijns HJ, Pinto YM: Meta-analysis of clinical characteristics of 299 carriers of LMNA gene mutations: do lamin $\mathrm{A} / \mathrm{C}$ mutations portend a high risk of sudden death? J Mol Med 2005, 83:79-83.

6. Bione S, Maestrini E, Rivella S, Mancini M, Regis S, Romeo G, Toniolo D: Identification of a novel X-linked gene responsible for Emery-Dreifuss muscular dystrophy. Nat Genet 1994, 8:323-327.

7. Nagano A, Koga R, Ogawa M, Kurano Y, Kawada J, Okada R, Hayashi YK, Tsukahara T, Arahata K: Emerin deficiency at the nuclear membrane in patients with Emery-Dreifuss muscular dystrophy. Nat Genet 1996, 12:254-259

8. Manilal S, Nguyen TM, Sewry CA, Morris GE: The Emery-Dreifuss muscular dystrophy protein, emerin, is a nuclear membrane protein. Hum $\mathrm{Mol}$ Genet 1996, 5:801-808.

9. Bonne G, Di Barletta MR, Varnous S, Bécane HM, Hammouda EH, Merlini L, Muntoni F, Greenberg CR, Gary F, Urtizberea JA, Duboc D, Fardeau M, Toniolo D, Schwartz K: Mutations in the gene encoding lamin A/C cause autosomal dominant Emery-Dreifuss muscular dystrophy. Nat Genet 1999, 21:285-288.

10. Raffaele Di Barletta M, Ricci E, Galluzzi G, Tonali P, Mora M, Morandi L, Romorini A, Voit T, Orstavik KH, Merlini L, Trevisan C, Biancalana V, Housmanowa-Petrusewicz I, Bione S, Ricotti R, Schwartz K, Bonne G, Toniolo $D$ : Different mutations in the LMNA gene cause autosomal dominant and autosomal recessive Emery-Dreifuss muscular dystrophy. Am J Hum Genet 2000, 66:1407-1412.

11. McKeon FD, Kirschner MW, Caput D: Homologies in both primary and secondary structure between nuclear envelope and intermediate filament proteins. Nature 1986, 319:463-468.

12. Fisher DZ, Chaudhary N, Blobel G: CDNA sequencing of nuclear lamins A and $C$ reveals primary and secondary structural homology to intermediate filament proteins. Proc Natl Acad Sci USA 1986, 83:6450-6454.

13. Aebi U, Cohn J, Buhle L, Gerace L: The nuclear lamina is a meshwork of intermediate-type filaments. Nature 1986, 323:560-564.

14. Lin F, Worman HJ: Structural organization of the human gene encoding nuclear lamin A and nuclear lamin C. J Biol Chem 1993, 268:16321-16326.
15. Fatkin D, MacRae C, Sasaki T, Wolff MR, Porcu M, Frenneaux M, Atherton J, Vidaillet HJ Jr, Spudich S, De Girolami U, Seidman JG, Seidman C, Muntoni F, Muehle $G$, Johnson W, McDonough B: Missense mutations in the rod domain of the lamin $A / C$ gene as causes of dilated cardiomyopathy and conduction-system disease. N Engl J Med 1999, 341:1715-1724.

16. Muchir A, Bonne G, van der Kooi AJ, van Meegen M, Baas F, Bolhuis PA, de Visser M, Schwartz K: Identification of mutations in the gene encoding lamins $\mathrm{A} / \mathrm{C}$ in autosomal dominant limb girdle muscular dystrophy with atrioventricular conduction disturbances (LGMD1B). Hum Mol Genet 2000, 9:1453-1459.

17. Bonne G, Mercuri E, Muchir A, Urtizberea A, Becane HM, Recan D, Merlini L, Wehnert M, Boor R, Reuner U, Vorgerd M, Wicklein EM, Eymard B, Duboc D, Penisson-Besnier I, Cuisset JM, Ferrer X, Desguerre I, Lacombe D, Bushby K, Pollitt C, Toniolo D, Fardeau M, Schwartz K, Muntoni F: Clinical and molecular genetic spectrum of autosomal dominant Emery-Dreifuss muscular dystrophy due to mutations of the lamin A/C gene. Ann Neurol 2000, 48:170-180

18. Brodsky GL, Muntoni F, Miocic S, Sinagra G, Sewry C, Mestroni L: Lamin A/C gene mutation associated with dilated cardiomyopathy with variable skeletal muscle involvement. Circulation 2000, 101:473-476.

19. Astejada MN, Goto K, Nagano A, Ura S, Noguchi S, Nonaka I, Nishino I, Hayashi YK: Emerinopathy and laminopathy clinical, pathological and molecular features of muscular dystrophy with nuclear envelopathy in Japan. Acta Myol 2007, 26:159-164.

20. Ura S, Hayashi YK, Goto K, Astejada MN, Murakami T, Nagato M, Ohta S, Daimon Y, Takekawa H, Hirata K, Nonaka I, Noguchi S, Nishino I: Limb-girdle muscular dystrophy due to emerin gene mutations. Arch Neurol 2007, 64:1038-1041.

21. Lu JT, Muchir A, Nagy PL, Worman HJ: LMNA cardiomyopathy: cell biology and genetics meet clinical medicine. Dis Model Mech 2011, 4:562-568.

22. Worman $\mathrm{HJ}$, Fong $L G$, Muchir A, Young SG: Laminopathies and the long strange trip from basic cell biology to therapy. I Clin Invest 2009, 119:1825-1836.

23. Arimura T, Helbling-Leclerc A, Massart $C$, Varnous $S$, Niel F, Lacène E, Fromes Y, Toussaint M, Mura AM, Keller DI, Amthor H, Isnard R, Malissen M, Schwartz K, Bonne G: Mouse model carrying H222P-Lmna mutation develops muscular dystrophy and dilated cardiomyopathy similar to human striated muscle laminopathies. Hum Mol Genet 2005, 14:155-169.

24. Muchir A, Pavlidis P, Decostre V, Herron AJ, Arimura T, Bonne G, Worman HJ: Activation of MAPK pathways links LMNA mutations to cardiomyopathy in Emery-Dreifuss muscular dystrophy. J Clin Invest 2007, 117:1282-1293.

25. Muchir A, Shan J, Bonne G, Lehnart SE, Worman HJ: Inhibition of extracellular signal-regulated kinase signaling to prevent cardiomyopathy caused by mutation in the gene encoding A-type lamins. Hum Mol Genet 2009, 18:241-247.

26. Wu W, Muchir A, Shan J, Bonne G, Worman HJ: Mitogen-activated protein kinase inhibitors improve heart function and prevent fibrosis in cardiomyopathy caused by mutation in lamin A/C gene. Circulation 2011, 123:53-61.

27. Muchir A, Reilly SA, Wu W, Iwata S, Homma S, Bonne G, Worman HJ: Treatment with selumetinib preserves cardiac function and improves survival in cardiomyopathy caused by mutation in the lamin $\mathrm{A} / \mathrm{C}$ gene. Cardiovasc Res 2012, 93:311-319.

28. Choi JC, Wu W, Muchir A, Iwata S, Homma S, Worman HJ: Dual specificity phosphatase 4 mediates cardiomyopathy caused by lamin A/C (LMNA) gene mutation. J Biol Chem 2012, 287:40513-40524.

29. Koressaar T, Remm M: Enhancements and modifications of primer design program Primer3. Bioinformatics 2007, 23:1289-1291.

30. Ponchel F, Toomes C, Bransfield K, Leong FT, Douglas SH, Field SL, Bell SM Combaret V, Puisieux A, Mighell AJ, Robinson PA, Inglehearn CF, Isaacs JD, Markham AF: Real-time PCR based on SYBR-Green I fluorescence: an alternative to the TaqMan assay for a relative quantification of gene rearrangements, gene amplifications and micro gene deletions. BMC Biotechnol 2003, 3:18.

31. Cray C, Rodriguez M, Zaias J, Altman NH: Effects of storage temperature and time on clinical biochemical parameters from rat serum. J Am Assoc Lab Anim Sci 2009, 48:202-204.

32. Seth A, Papas TS: The c-ets-1 proto-oncogene has oncogenic activity and is positively autoregulated. Oncogene 1990, 5:1761-1767.

33. Tohgo A, Pierce KL, Choy EW, Lefkowitz RJ, Luttrell LM: Beta-Arrestin scaffolding of the ERK cascade enhances cytosolic ERK activity but inhibits ERK-mediated transcription following angiotensin AT1a receptor stimulation. J Biol Chem 2002, 277:9429-9436. 
34. Lammerding J, Schulze PC, Takahashi T, Kozlov S, Sullivan T, Kamm RD, Stewart CL, Lee RT: Lamin A/C deficiency causes defective nuclear mechanics and mechanotransduction. J Clin Invest 2004, 113:370-378.

35. Dauer WT, Worman HJ: The nuclear envelope as a signaling node in development and disease. Dev Cell 2009, 17:626-638.

36. Chen YW, Zhao P, Borup R, Hoffman EP: Expression profiling in the muscular dystrophies: identification of novel aspects of molecular pathophysiology. J Cell Biol 2000, 151:1321-1336.

37. Haslett JN, Sanoudou D, Kho AT, Bennett RR, Greenberg SA, Kohane IS, Beggs AH, Kunkel LM: Gene expression comparison of biopsies from Duchenne muscular dystrophy (DMD) and normal skeletal muscle. Proc Natl Acad Sci USA 2002, 99:15000-15005.

38. Burks TN, Cohn RD: Role of TGF- $\beta$ signaling in inherited and acquired myopathies. Skeletal Muscle 2011, 1:19.

39. Kumar A, Khandelwal N, Malya R, Reid MB, Boriek AM: Loss of dystrophin causes aberrant mechanotransduction in skeletal muscle fibers. FASEB J 2004, 18:102-113.

40. Lang JM, Esser KA, Dupont-Versteegden EE: Altered activity of signaling pathways in diaphragm and tibialis anterior muscle of dystrophic mice. Exp Biol Med 2004, 229:503-511.

41. Smythe GM, Forwood JK: Altered mitogen-activated protein kinase signaling in dystrophic (mdx) muscle. Muscle Nerve 2012, 46:374-383.

42. Griffin MA, Feng $H$, Tewari M, Acosta P, Kawana M, Sweeney HL, Disher DE: $Y$-sarcoglycan deficiency increases cell contractility, apoptosis and MAPK pathway activation but does not affect adhesion. J Cell Sci 2005, 118:1405-1416.

43. Barton ER: Impact of sarcoglycan complex on mechanical signal transduction in murine skeletal muscle. Am J Physiol Cell Physiol 2006, 290:C411-C419.

44. Kumar A, Yamauchi J, Girgenrath T, Girgenrath M: Muscle-specific expression of insulin-like growth factor 1 improves outcome in Lama2Dy-w mice, a model for congenital muscular dystrophy type 1A. Hum Mol Genet 2011, 20:2333-2343.

45. Muchir A, Pavlidis P, Bonne G, Hayashi YK, Worman HJ: Activation of MAPK in hearts of EMD null mice: similarities between mouse models of $X$ linked and autosomal dominant Emery Dreifuss muscular dystrophy. Hum Mol Genet 2007, 16:1884-1895.

46. Prado CM, Bekaii-Saab T, Doyle LA, Shrestha S, Ghosh S, Baracos VE, Sawyer MB: Skeletal muscle anabolism is a side effect of therapy with the MEK inhibitor: selumetinib in patients with cholangiocarcinoma. $\mathrm{Br} J$ Cancer 2012, 106:1583-15836.

47. Chapman MS, Miner JN: Novel mitogen-activated protein kinase kinase inhibitors. Expert Opin Investig Drugs 2011, 20:209-220.

48. Trujillo Jl: MEK inhibitors: a patent review 2008-2010. Expert Opin Ther Pat 2011, 21:1045-1069.

doi:10.1186/2044-5040-3-17

Cite this article as: Muchir et al:: Inhibition of extracellular signalregulated kinase $1 / 2$ signaling has beneficial effects on skeletal muscle in a mouse model of Emery-Dreifuss muscular dystrophy caused by lamin A/C gene mutation. Skeletal Muscle 2013 3:17.

\section{Submit your next manuscript to BioMed Central and take full advantage of:}

- Convenient online submission

- Thorough peer review

- No space constraints or color figure charges

- Immediate publication on acceptance

- Inclusion in PubMed, CAS, Scopus and Google Scholar

- Research which is freely available for redistribution 